\title{
Wildfire cause analysis: four case-studies in southern Italy
}

\author{
Lovreglio $\mathbf{R}^{(1)}$, Leone $\mathbf{V}^{(1)}$, Giaquinto $\mathrm{P}^{(1)}$, Notarnicola $\mathrm{A}^{(2)}$
}

Forest fires in Italy are mainly caused by humans, and directly depend on social behavior, whether voluntary (arson) or involuntary (negligence). Despite the progress in knowledge made with studying the physical facets of the phenomenon, causes and motives of human-related fire remain mostly unknown. This paper proposes the implementation of the Delphi method (an interactive expert-questionnaire process) in order to assess why fires are ignited. In four study cases, within a high fire incidence area (southern Italy), the Delphi technique identified as major cause of negligence the use of fire in agriculture and, as major causes of voluntary fires, motives related to seasonal labor. The main results in terms of frequency are: (i) for involuntary events (negligence), experts unanimously identified the relevant importance of negligent use of agricultural fires, particularly stubble burning (13.99\% of responses). For (ii) voluntary fires (arson), results highlight the relative importance of fires ignited by seasonal workers as an instrument to force or maintain employment $\mathbf{( 8 . 4 1 \%}$ of responses).

Keywords: Delphi method, Fire causes, Agricultural fires, Ignition motives, Arson fires, Negligent fires, Panel of fire experts

\section{Introduction}

Worldwide it has been determined that humans are responsible for about $90 \%$ of biomass burning, with only a small percentage of natural fires contributing to the total amount of vegetation burned.

The FAO Fire Management and Global Assessment 2006 Report offers some rough estimations on fire causes in the world. According to this report, the Mediterranean region accounts the larger proportion of human caused fires in the world $(95 \%)$ followed by South Asia (90\%), South America (85\%) and Northeast Asia (80\% - FAO 2007). Surprisingly, wildfires are still considered as natural hazards, even by some authoritative sources (NASA 2003); even in the EU, in different Frame Programs such as FP6 and FP7, still in progress, fires are regarded as natural hazards.

(1) Department of Crop Systems, Forestry and Environmental Sciences, University of Basilicata, v.le dell'Ateneo Lucano 10, I85100 Potenza (Italy); (2) Department of Psychology, University of Bari, p.zza Umberto I 1, I-70122 Bari (Italy).

a) Raffaella Lovreglio

(raffaella.lovreglio@unibas.it)

Received: Aug 29, 2009 - Accepted: Oct 28, 2009

Citation: Lovreglio R, Leone V, Giaquinto P, Notarnicola A, 2010. Wildfire cause analysis: four case-studies in southern Italy. iForest 3 : 8-15 [online: 2010-01-22] URL:

http://www.sisef.it/iforest/show.php? id $=521$
Forest fires are neither a natural occurrence nor a natural disaster, with the exception of those fires started by natural agents. They are, on the contrary, an anthropogenic phenomenon which exclusively and directly depends on social behavior, whether it be voluntary or involuntary (Leone et al. 2002).

Today we have knowledge of some aspects of fire: "what", "when", "where" it happens. The knowledge of fire, as a complex physical-chemical reaction, allows good prediction of its behavior, through the use of a wide set of fire behavior/spread models that have been implemented in the United States, Canada, Australia, Spain, Greece since the 1950's and 60's.

Remote sensing and satellite imagery assist to determine the time, place and extent of active fires around the world, with special emphasis on their distributive and seasonal pattern, on energy, gas release, etc. (NASA 2009).

Yet we still do not know enough about who starts wildfires and why. What we know about the subject is mainly included in a list of credible (and sometimes obvious) motives for starting fires. What we do not have is the capability of filling the gap between the advanced knowledge of the physical facets of the phenomenon and the very reasons of its genesis (Leone \& Lovreglio 2003).

FAO (1999) notes that "It is next to impossible to design specific fire prevention campaigns if one cannot identify the causes of wildfires in a systematic way. If critical fire starting causes remain unknown, then it becomes extremely difficult to mount a signi- ficant prevention effort".

Similarly, it has been stated that "Until our ability to determine the causes of forest fires improves, our efforts at prevention will essentially remain shots in the dark..." (Environment Policy 2003).

Causes are more diverse than is often assumed to be the case, and fire initiation is neither as random, nor, in some cases, as meaningless as some analysis suggest (Leone et al. 2003). Understanding the reasons why fires start is a crucial factor to prevent or reduce their incidence. It is important to avoid the piecemeal approach to fire which concentrates mainly on fire suppression (Wilson 1976), and hence mainly focuses on fighting fires and developing the infrastructure to detect and facilitate access to fire, whereas inadequate attention is given to addressing the underlying causes of harmful fires (Jackson \& Fisher 2001).

Databases today contain a high percentage of unknown causes of wildland fire. In many countries the percentage of unknown fire causes reaches up to $70 \%$ or $80 \%$ (UNECE 2008). No proper wildland fire planning can be done with such a degree of uncertainty.

Understanding the motive behind the cause of fires may enhance investigative efforts and focus on improving prevention through social behaviour modifications.

There is an ongoing need to improve the knowledge of this point, which is a pre-condition for the implementation of suitable solutions.

The main causes of wildfires in Italy, as described in official statistics, follow the categories suggested by EEC Regulation No 804/94 (no longer in effect) which established a Community system of information on forest fires.

In 2001 the first complete survey of wildfires carried out by the State Forestry Service assessed that the main cause of fires was arson, which caused $59.3 \%$ of the fires. The rest of the fires were a result of negligence $(17.8 \%)$, natural $(0.7 \%)$ or unknown causes (22.2\% - MIPAAF-CFS 2002).

On a longer period, the Italian fire database for the most recent period (1997-2007), when causality records are more reliable, shows the following official percentage of causes:

- negligence: $17.27 \%$

- voluntary: $58.96 \%$

- natural: $1.23 \%$

- unknown: $22.54 \%$.

The motives for arson were grouped into three categories, namely: profit-seeking, manifestations of protest, resentment or insensitivity toward forests.

The main category was revealed as "profitseeking", to which 2.992 incidents have been attributed, equivalent to $69.9 \%$ of arson 
cases and $41.9 \%$ of total fires; 1085 fires (25.4\% of arson cases and $15.3 \%$ of total fires) have been attributed to "manifestations of protest, resentment and insensitivity toward forests".

Of the three categories taken into consideration of fires caused by negligence, the most frequent was the category of fires caused by agricultural and forestry activities (1 492 incidents, equivalent to $60.8 \%$ of fires involving negligence), followed by the category of fires caused by cigarette stubs and matches (552 incidents or $22.5 \%$ of fires by negligence).

As for motivations behind causes, only since 2004 have standard forms for forest fire statistics been implemented to verify the proven or suspected motive of each fire, following a list of official denominations which are reported in Annex 1, together with their four digit code.

In any case assessment of causes, mainly of voluntary fires, is usually in the opinion of the reporting forestry officer filling the fire statistic form and secure determinations are made in a minority of cases, as in every country, only when culprits are brought to justice. This occurs in Italy in about $7 \%$ of the events (Corrado 2008). Many doubts remain therefore about reliability of the distribution of fire frequency by causes, mainly for voluntary fires $(58.96 \%$ of total), which are probably overemphasized (Bovio 2005).

Our study aims to contribute to a better knowledge of motives of fire causes, suggesting the use of a rather simple but interesting tool: the Delphi technique.

\section{Materials and methods}

\section{The Delphi Technique}

The Delphi technique was originally developed in the 1950s by Olaf Helmer and Norman Dalkey, scientists at the Rand Corporation, as an iterative process for forecasting the likelihood that certain events will occur; namely, the effects of a massive atomic attack on the United States. Project Delphi was the name given to an Air Forcesponsored Rand Corporation study, starting in the early 1950's, concerning the use of expert opinion to "obtain the most reliable consensus of opinion of a group of experts by a series of intensive questionnaires interspersed with controlled opinion feedback." The subject of this study was the application of "expert opinion to the selection, from the point of view of a Soviet strategic planner, of an optimal U.S. industrial target system and to the estimation of the number of A-bombs required to reduce the munitions output by a prescribed amount" (Turoff 1970).

It is a study method which generates ideas and facilitates consensus among individuals who have unique knowledge to share, designed as a means of scientific prediction
(Baughman 1989).

The Delphi technique uses a panel of carefully selected experts who answer a series of questions, through either correspondence or face-to-face discussion. The accuracy of the prediction depends on competence, experience, objectivity and perception of the discerning judge.

Each round of questioning is followed by feedback on the preceding round of replies, usually presented anonymously. The experts are encouraged to revise their earlier answers in light of the other group member's responses. It is believed that during this process the range of answers will decrease and the group will converge towards the "correct" answer. After several rounds, the process is complete and the average scores determine the final answers.

The Delphi technique may be used in areas where there is an absence of sufficient data and/or an incomplete theory on cause and effect in regard to the phenomena under study. Sitting between knowledge and speculation, the informed deliberations of the panel of experts may best be considered an informed judgment.

The Delphi procedure has become a popular tool in technological forecasting and a single definition is no longer appropriate for its numerous applications.

Distinguishing features of the Delphi technique are:

- anonymity;

- iteration with controlled feedback;

- statistical group response;

- expert input.

The Delphi technique generally includes several steps:

- the specification of a topic or subject be investigated;

- the construction of an ad hoc questionnaire for data collection;

- the selection of a panel of experts on the topic being investigated;

- the weighting of the opinions of the experts by means of the questionnaire;

- the summary of the data resulting from the initial measurement;

- the communication of the results of the initial weighting of opinions as feedback to all the respondents;

- a re-evaluation of the opinions of the respondents, as they have been informed and may have been changed by their knowledge of earlier results including of other respondents' supporting comments for their opinions;

- an analysis, interpretation, and presentation of the data and the writing of a final report. While the Delphi is considered a forecasting procedure due to its significant use in that area, there is a variety of other application areas among which we find developing causal relationships in complex economic or social phenomena, distinguishing and clari- fying real and perceived human motives; this latter feature correctly fits the analysis of fire motivations in areas where fires frequently occur (Linstone \& Turoff 2002) but with little knowledge about their motives.

Delphi has been used in many fields of Environmental Sciences: recreation (Anderson \& Schneider 1993, habitat suitability evaluation (Crance 1987), quality of habitat (Schuster et al. 1985), and fishery (Zuboy 1980).

In the field of forest fires (De Las Heras et al. 2007), the Delphi technique has been used in a few cases in the United States to explore the current state of wildland fire communication from the perspective of wildland fire communicators (Clute 2000); in Spain (FAB Consultores 1990) it has been used to analyze the causes of fires in the Balearic Islands, in a survey of arson fires (ICONA 1995), in a survey on fire prevention and communication (Ministerio de Medio Ambiente 1997) and, more recently, in a survey on the perception of forest fires by the Spaniards (APAS 2003, Dolzreuss \& Irastorza 2005)

In Italy, the only known implementation of the technique is by the authors (Leone \& Lovreglio 2003, Lovreglio et al. 2006, Lovreglio et al. 2008) firstly in the Fire Control Plan for the Gargano National Park, where the Delphi method and kernel density estimation technique permitted to analyze in depth the complex dynamics of an extreme fire-prone territory.

The Delphi technique, for the assessment of fire motives in this paper, has been implemented in four different areas in Southern Italy, all of them marked by a more or less severe fire occurrence (Fig. 1).

\section{Study area}

Study areas, which have been selected in terms of increasing territorial surface, varying from 100000 to 1000000 hectares, are as reported below.

\section{Area 1}

Comunità Montana Vallo di Diano (Mountain Community are the Upland Development Authorities established by the Italian Law on the Development of Highlands, Law 1102 of 1971), hereafter referred to simply as C.M. Vallo di Diano, inside the National Park of Cilento and Vallo di Diano, in the province of Salerno, region Campania.

C.M. consists of 15 municipalities, for a total surface of 71838 hectares, with medium high elevation (550 to $1.900 \mathrm{~m}$ a.s.1.) and an extreme climatic variability.

Forest cover is 27884 ha, i.e., $39 \%$ of the total area; about half of them are transition forest, developed from secondary succession.

Average number of fires per year (19982004): 45. 
Area 2

National Park of Gargano, in the province of Foggia (region Apulia). Gargano is the large limestone promontory which juts far out into the Adriatic, on Italy's East coast.

Land use is very complex, with many permanent meadows of primary origin vegetating in the upper part, intermingled with woods, mainly high forests and coppices, which cover about 50640 hectares.

The territory was originally devoted to pasture, with croplands only in the peripheral strip.

In the inner part, the calcareous basement is partially covered by deciduous broadleaved forests, ranging from high stands of Fagus sylvatica L. gradually succeeded by dense, Quercus cerris L. forests, to scrubby Mediterranean macchia, the most widespread form of natural vegetation in the typically Mediterranean parts of the area. A wide peripheral strip of low elevation, high forest of native Pinus halepensis Mill. characterizes the area.

The National Park of Gargano consists of 19 municipalities and about 262000 hectares of land.

The average number of fires per year (1974-2001): 152

Gargano is among the most severely fire affected areas in Italy and probably in the Mediterranean basin (Leone et al. 2002). As a matter of fact, in the summer of 2007 the territory of the National Park once again was ravaged by a disastrous voluntary fire which caused the loss of lives and enormous damages.

\section{Area 3}

Province of Bari, in the Apulia region. On the south eastern tip of Italy, the province of Bari, in the region Apulia, is a wide area of 513831 hectares. The terrain is mainly flat, with its highest elevation being the inner Murge Plateau, a wide and tabular (maximum elevation $686 \mathrm{~m}$. a.s.l.) calcareous high plateau, poorly developed and scarcely inhabited, originally devoted to pasture, now included in the National Park of Alta Murgia.

Forest cover of the Province is only 24975 hectares, mainly degraded coppices of Quercus spp.; the majority of them are small surfaces intermingled with cropland.

Plantations of Pinus halepensis and Cupressus made in the 1930's and 50's are frequent, with wide surfaces, in the inner part of the province, on the higher sites of the plateau. All of them were functional to soil protection against erosion, mainly water and wind erosion.

The average number of fires per year (1996-2001): 68.

\section{Area 4}

Basilicata region. Basilicata is a small re-

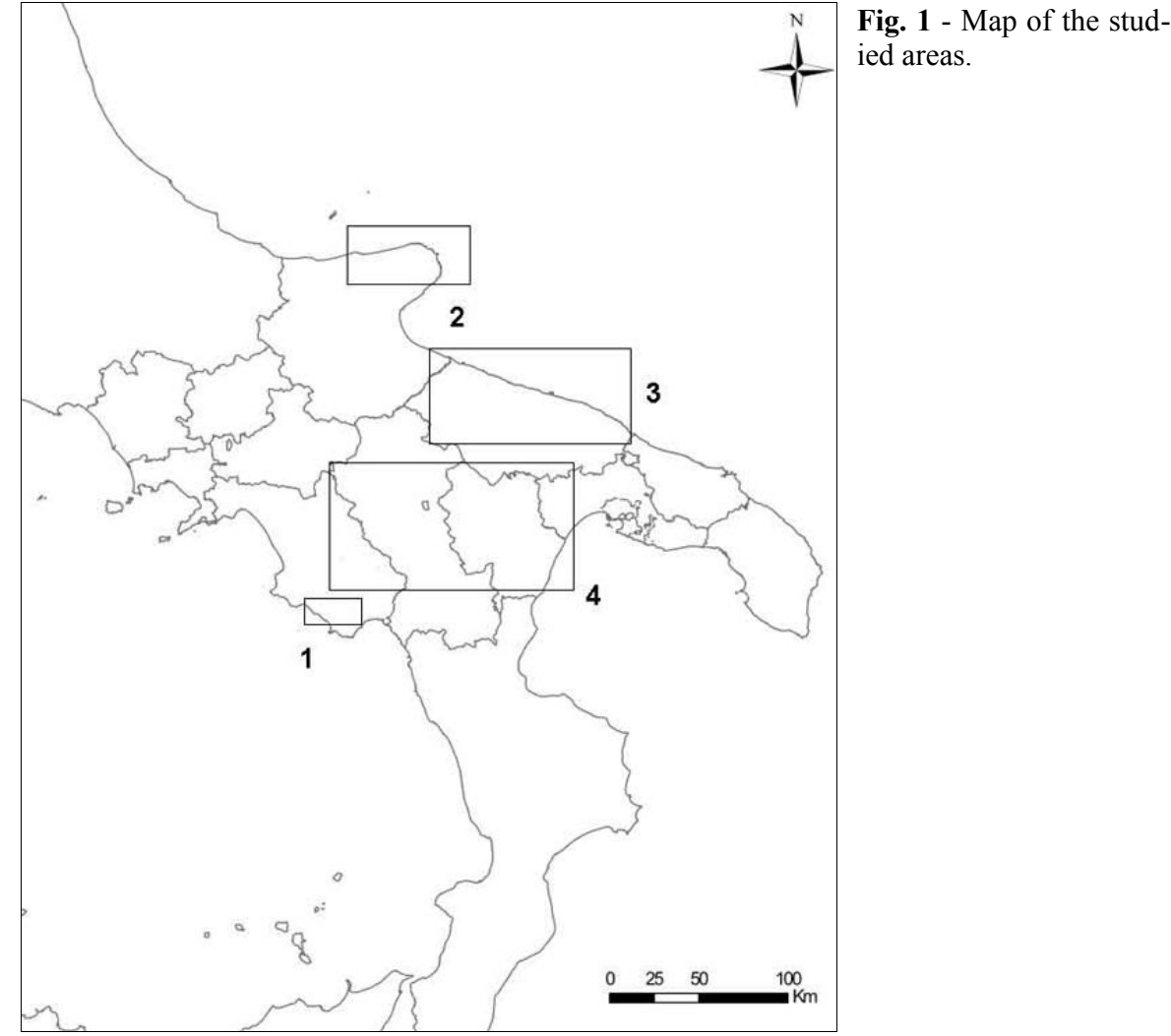

gion with a total area of 999461 hectares, situated in southern Italy, with two short coastlines on both the Ionian and the Tyrrhenian Sea. Its western part, province of Potenza, is roughly mountainous, with elevations over $2000 \mathrm{~m}$. a.s.l. and is covered by about 270000 hectares of forest. The eastern part is a rather flat province (Matera), with a much less important forest surface (80 657 hectares) as a result of a historically dramatic deforestation carried out in the XIX $^{\text {th }}$ century, intended to recuperate agricultural land for extensive wheat cultivation purposes.

The region includes two National Parks: the National Park of Val d'Agri and Lagonegrese and the National Park of Pollino, the widest National Park in Italy; in the latter rare and precious endemic species grow such as Pinus heldreichii H. Christ, 1863 (Bosnian pine). Broadleaved forests (mainly Quercus spp. and Fagus sylvatica L.) represent about $51.8 \%$ of total forested area of the Region.

The average number of fires per year (1992-2003): 372.

All the study areas represent the typical Mediterranean climate pattern, where hot and dry summers are a predisposing fire factor.

With regard to wildfires, all sites are high risk areas, in accordance to European Economic Community (CEE) Reg. 2158/92, for high frequency (number of fires per year), high density (number of fires / year / forest area), high burned area, medium or high fire impact (forest burned area / year / forest land).

Sites 3 and 4 are in the Apulia Region, which has the minimum percentage of forested land (forestry ratio) at the national level (only $7.7 \% v s$. a national value of $28.8 \%$ ), but a percentage of voluntary fires much above the national average (MIPAAF-CFS 2002) and relatively to forestry ratio the highest percentage of burned forested land among the Italian regions (Leone 1997b).

All areas are economically marginal, being included in the fourth quartile in the economic classifications of European Union (EU) Regions (NUTS II) and at the lower end of the national level.

Having a Gross Domestic Product (GDP), which is the basic measure for economic activity, $<75 \%$ of EU 15 average, Campania, Apulia and Basilicata were included in the so called Objective 1 group of the EU together with Abruzzo (until 31/12/2000), Calabria, Molise, Sicily, and Sardinia.

It leaves no doubt that Objective 1 Regions can be described as "less developed". Among them, the three regions considered in this study in which the condition of marginality of the same sub-areas are accompanied by the presence of some types of voluntary wildfires, mainly related to labor conflicts.

A panel of experts is the cornerstone of the Delphi technique: in the case-studies, experts in the particular field of forest fires were found through the professionals working for 
governmental and non-governmental organizations; namely, the foresters of CFS (State Forestry Department) - areas 1.2.4 - and Provincial rangers (area 3).

Number of expert for each area is given in Tab. 1. The four panels of experts therefore included a total of 156 respondents.

Foresters belong to CFS, Corpo Forestale dello Stato (State Forestry Department), a National Police Agency in Italy, responsible for protecting Italy's natural resources, the environment, countryside and ecosystems, particularly National Parks and National Forests. Its best known protection duty is fighting wildfires.

Foresters stationed at Forest Stations are required to keep records of forest fire statistics. After each fire, they must fill out a standard statistic form, explaining (among other things) the motivation and cause of fire.

They all have considerable experience in fire and social problems of the territory, particularly those working in stations that are commanded by a Warrant Officer who is usually at the end of his/her career. It leaves, therefore, no doubt that their experience in the specific area of forest fires causes and indepth knowledge of their territory, is confirmed.

Provincial rangers belong to a police agency as well, but on the local level.

They are trained as forestry rangers and provide hunting and fishing control services, enforcement of environmental laws; rangers are ex officio watersheds, fish, game and fire guardians and collaborate with CFS in fire fighting, mainly alarm and first attack.

Personnel involved in the experts' panel is therefore directly and permanently involved in forest fire control and statistic activities. For this reason, they must be considered well knowledgeable and experienced in the subject. In both cases, experts are organized in a hierarchical, military-like organization.

Among the experts, we did not include professionals from the National Fire Brigade, since structural firefighting (and not wildfires) is their functional responsibility in accordance with the Law, Act 353/2000. This organization only provides assistance in structure protection on an emergency basis to save lives in the event of a wildfire.

Structured questioning was achieved through the use of ad hoc questionnaires where all official motives of forest fires, recognized by the State Forestry Department (MIPAAF-CFS 2002) and which are routinely used by the same experts in forest fire statistics (see Annex 1), are reported.

The use of the anonymous questionnaire provided the group members the freedom to express their opinion without feeling pressured by the wider group or dominant members.

One of the main problems with such a

Tab. 1 - Study-areas and fire motives in order of decreasing frequency.

\begin{tabular}{|c|c|c|c|c|c|c|c|}
\hline \multirow{2}{*}{\multicolumn{2}{|c|}{$\begin{array}{c}\text { C. M. Vallo di Diano } \\
\text { Number of experts } \\
\mathrm{N}=8\end{array}$}} & \multicolumn{2}{|c|}{ National Park of Gargano } & \multicolumn{2}{|l|}{ Province of Bari } & \multicolumn{2}{|l|}{ Region Basilicata } \\
\hline & & $\begin{array}{c}\text { Number of exper } \\
\qquad \mathbf{N}=\mathbf{3 4}\end{array}$ & & $\begin{array}{c}\begin{array}{c}\text { Number of experts } \\
\mathbf{N}=\mathbf{5 8}\end{array}\end{array}$ & & $\begin{array}{c}\text { Number of experts } \\
\qquad \mathrm{N}=56\end{array}$ & \\
\hline Main motives & $\begin{array}{l}\text { Freq. } \\
(\%)\end{array}$ & Main motives & $\begin{array}{c}\text { Freq. } \\
(\%)\end{array}$ & Main motives & $\begin{array}{c}\text { Freq. } \\
(\%)\end{array}$ & Main motives & $\begin{array}{l}\text { Freq. } \\
(\%)\end{array}$ \\
\hline $\begin{array}{l}\text { Fire set for cleaning on bor- } \\
\text { ders of croplands or in aban- } \\
\text { doned agrarian plots. }\end{array}$ & 12.50 & "Fire industry" & 7.55 & $\begin{array}{l}\text { Fire set for stubble burn- } \\
\text { ing }\end{array}$ & 13.99 & $\begin{array}{l}\text { Fire set for stubble burn- } \\
\text { ing }\end{array}$ & 11.16 \\
\hline $\begin{array}{l}\text { Fire set by farmers for planta- } \\
\text { tion cleaning after harvest }\end{array}$ & 10.94 & $\begin{array}{l}\text { Pyromania and myth } \\
\text { mania }\end{array}$ & 7.55 & "Fire industry" & 10.56 & $\begin{array}{l}\text { Fire set for cleaning on } \\
\text { borders of croplands or in } \\
\text { abandoned agrarian plots. }\end{array}$ & 8.48 \\
\hline Fire set for stubble burning & 10.94 & $\begin{array}{l}\text { Fire set for stubble } \\
\text { burning }\end{array}$ & 7.19 & $\begin{array}{l}\text { Fire set by the auxiliary } \\
\text { workers who are retained } \\
\text { by national forest fire ser- } \\
\text { vices }\end{array}$ & 8.41 & $\begin{array}{l}\text { Pyromania and myth } \\
\text { mania }\end{array}$ & 7.97 \\
\hline $\begin{array}{l}\text { Carelessly discarded cigarette } \\
\text { butts or matches on road banks }\end{array}$ & 9.38 & $\begin{array}{l}\text { Fire set by the auxili- } \\
\text { ary workers who are } \\
\text { retained by national } \\
\text { forest fire services }\end{array}$ & 5.76 & Fires started by lightning & 6.44 & $\begin{array}{l}\text { Fire set for pasture renov- } \\
\text { ation }\end{array}$ & 7.62 \\
\hline $\begin{array}{l}\text { Fire set to obtain products de- } \\
\text { riving from fire passage }\end{array}$ & 9.38 & $\begin{array}{l}\text { Fire caused as protest } \\
\text { against limitations im- } \\
\text { posed in conservation } \\
\text { areas }\end{array}$ & 5.76 & $\begin{array}{l}\text { Fire caused with the intent } \\
\text { of earning from the re- } \\
\text { moval of vegetation for } \\
\text { the purpose of building } \\
\text { speculation }\end{array}$ & 5.39 & $\begin{array}{l}\text { Fire caused by conflicts } \\
\text { between or revenge } \\
\text { against owners, ownership } \\
\text { controversies }\end{array}$ & 6.68 \\
\hline $\begin{array}{l}\text { Fire caused by the creation or } \\
\text { renewal of pastures at the ex- } \\
\text { pense of forests }\end{array}$ & 7.81 & $\begin{array}{l}\text { Fire caused by con- } \\
\text { flicts between or re- } \\
\text { venge against owners, } \\
\text { ownership controver- } \\
\text { sies }\end{array}$ & 5.40 & $\begin{array}{l}\text { Pyromania and myth } \\
\text { mania }\end{array}$ & 4.53 & $\begin{array}{l}\text { Fire set by farmers for } \\
\text { plantation cleaning after } \\
\text { harvest }\end{array}$ & 6.25 \\
\hline $\begin{array}{l}\text { Fire caused by conflicts } \\
\text { between or revenge against } \\
\text { owners, ownership controver- } \\
\text { sies }\end{array}$ & 6.25 & $\begin{array}{l}\text { Fire set as revenge or } \\
\text { retaliation against pub- } \\
\text { lic administration }\end{array}$ & 5.40 & $\begin{array}{l}\text { Fire set for pasture renov- } \\
\text { ation }\end{array}$ & 4.31 & $\begin{array}{l}\text { Carelessly discarded ci- } \\
\text { garette butts or matches } \\
\text { on road banks }\end{array}$ & 5.82 \\
\hline $\begin{array}{l}\text { Carelessly discarded cigarette } \\
\text { butts or matches in coun- } \\
\text { tryside }\end{array}$ & 4.69 & $\begin{array}{l}\text { Fire set for cleaning on } \\
\text { borders of croplands } \\
\text { or in abandoned } \\
\text { agrarian plots }\end{array}$ & 4.68 & $\begin{array}{l}\text { Fire caused by conflicts } \\
\text { between or revenge } \\
\text { against owners, ownership } \\
\text { controversies }\end{array}$ & 4.31 & Fires started by lightning & 3.91 \\
\hline others & 28.11 & others & 50.35 & others & 42.06 & others & 42.11 \\
\hline
\end{tabular}


Tab. 2 - Decreasing frequency of most relevant motives (all areas included).

\begin{tabular}{lcc}
\hline \multicolumn{1}{c}{ Motive } & $\begin{array}{c}\text { Max. observed } \\
\text { frequency (\%) }\end{array}$ & $\begin{array}{c}\text { Code of } \\
\text { motives }\end{array}$ \\
\hline Stubble burning & 13.99 & 3104 \\
Agricultural uses & 12.50 & 3101 \\
Pruning rests burning & 10.94 & 3102 \\
Fire-fighters & 10.56 & 4008 \\
Cigarettes & 9.38 & 3001 \\
Mushrooming & 9.38 & 4010 \\
Agricultural uses & 8.48 & 3101 \\
Fire-fighters & 8.41 & 4006 \\
Pyromaniacs & 7.97 & 4108 \\
Renewal of pastures & 7.81 & 4001 \\
Agricultural uses & 7.62 & 3103 \\
All others & $<7.55$ & - \\
\hline
\end{tabular}

structure is actually to avoid negative group dynamics that may emerge, such as domination by key individuals, prestige of a certain participant, shyness of certain participants and above all, superior in rank.

The panel members met face-to-face with the monitor (or modulator) of the Delphi inquiry (areas 1,2,3) or were contacted via mail (only for area 4): this latter option is considered acceptable (Dunham 1998).

Experts, who usually identify fire causes for their activity, as already mentioned, were given the questionnaire, reporting the list of motives and identification codes. They were asked to "vote" for the eight most important and/or relevant motives in the territory where they act and then to rank them in order of decreasing importance, scoring from 1 to 8,1 being the most important and so on.

A list of motives, with their four-digit identification code, is presented in Annex 1 (MIPAAF-CFS 2002): it contains the 43 posin Italy and is divided into five groups (natural, accidental, negligent, deliberate, doubt). Cause categories are those officially adopted in Italy by the Italian State Forestry Department for forest fire statistics.

The motives maintain their original statement, but explanatory notes are added.

Experts were consequently asked questions that specifically refer to their respective areas of expertise when filling out the forest fire statistic forms, since wildfire motives Controlled feedback was achieved by dissible official motives behind the cause of fire and relative codes are very familiar to them. cussing responses among the panel members of areas 1, 2, 3 and Delphi modulator.

Responses were processed and results presented to experts. The panel members were then asked if this information had changed their opinion in any way and if they wanted to modify their responses to any question.

None of the participants reconsidered their responses after feedback. Experts in area 4, who were contacted by mail, preliminarily stated that they would not accept any further meetings or questionnaire sending.

Far from being a breakdown, we consider that lack of reconsidering responses avoided a tendency to force a middle-of-the-road consensus or give responses which experts think the monitoring group want to hear.

The risk in the method is actually that of generating an artificial consensus. In addition, we cannot exclude the so called "Hawthorn Effect", which is the psychological response in which subjects alter their behavior because they are aware they are participating in a study.

\section{Results}

Tab. 1, Tab. 2 and Tab. 3 report respectively the most frequent motives, as identified by the experts and their rank-ordering, which is the modal value or mode of rankscores.

We did not use their arithmetic mean, which is not suitable for use with nominal or ordinal data (the scores are ordinal value only representing position of order, not quantity).

Tab. 3 - Rank-ordering (1 to 8) of most frequent fire motives in study-areas.

\begin{tabular}{|c|c|c|c|c|}
\hline $\begin{array}{l}\text { Rank- } \\
\text { Order }\end{array}$ & C. M. Vallo di Diano & National Park of Gargano & Province of Bari & Region Basilicata \\
\hline 1 & $\begin{array}{l}\text { Agricultural uses, Rests } \\
\text { burning }\end{array}$ & Stubble burning & Stubble burning, Fire industry & $\begin{array}{l}\text { Stubble burning, } \\
\text { Pyromania and myth mania }\end{array}$ \\
\hline 2 & Stubble burning & $\begin{array}{l}\text { Renewal of pastures } \\
\text { Auxiliary workers }\end{array}$ & $\begin{array}{l}\text { Stubble burning, Auxiliary } \\
\text { workers, Ownership controver- } \\
\text { sies }\end{array}$ & $\begin{array}{l}\text { Agricultural uses, Pasture } \\
\text { renovation, Stubble burning }\end{array}$ \\
\hline 3 & $\begin{array}{l}\text { Agricultural uses, Rests } \\
\text { burning, Stubble burning, Re- } \\
\text { newal of pastures, Mushroom- } \\
\text { ing, Ownership controversies }\end{array}$ & $\begin{array}{l}\text { Auxiliary workers, Fire } \\
\text { industry, Retaliation against } \\
\text { public administration }\end{array}$ & $\begin{array}{l}\text { Stubble burning, Cleaning of } \\
\text { road/railroad, Auxiliary } \\
\text { workers }\end{array}$ & $\begin{array}{l}\text { Agricultural uses Stubble burn- } \\
\text { ing }\end{array}$ \\
\hline 4 & Cigarettes, Agricultural uses & Stubble burning, Fire industry & Pasture renovation, Fire industry & Cigarettes, Pasture renovation \\
\hline 5 & $\begin{array}{l}\text { Rests burning, Mushrooming, } \\
\text { Ownership controversies }\end{array}$ & Renewal of pastures & $\begin{array}{l}\text { Building speculation, Auxiliary } \\
\text { workers }\end{array}$ & $\begin{array}{l}\text { Pasture renovation, } \\
\text { Ownership controversies }\end{array}$ \\
\hline 6 & $\begin{array}{l}\text { Fire-crackers and } \\
\text { bottle-rockets }\end{array}$ & Auxiliary workers & $\begin{array}{l}\text { Hot vehicle exhaust pipes, } \\
\text { Building speculation, } \\
\text { Ownership controversies }\end{array}$ & $\begin{array}{l}\text { Cigarettes, Retaliation against } \\
\text { public administration, Mush- } \\
\text { rooming }\end{array}$ \\
\hline 7 & Renewal of pastures & Pyromaniacs & $\begin{array}{l}\text { Lightning, Hot vehicle exhaust } \\
\text { pipes, Auxiliary workers, Reta- } \\
\text { liation against public admini- } \\
\text { stration }\end{array}$ & $\begin{array}{l}\text { Lightning, Sparks from brake } \\
\text { shoes of trains, Auxiliary } \\
\text { workers, Ownership controver- } \\
\text { sies }\end{array}$ \\
\hline 8 & Cigarettes & $\begin{array}{l}\text { Lightning Cigarettes, Stubble } \\
\text { burning, Forestry operations } \\
\text { Ownership controversies, Pyro- } \\
\text { mania and myth mania }\end{array}$ & $\begin{array}{l}\text { Lightning, Pyromania and myth } \\
\text { mania }\end{array}$ & Lightning, Power lines \\
\hline
\end{tabular}


Tab. 4 - Percentage of different forest causes in the study regions (2001) from the official statistics.

\begin{tabular}{lccc}
\hline \multicolumn{1}{c}{$\begin{array}{c}\text { Fire causes } \\
\text { (\%) }\end{array}$} & \multicolumn{3}{c}{ Region } \\
\cline { 2 - 4 } & Apulia & Basilicata & Campania \\
\hline Natural & 0.7 & 0.3 & 0.4 \\
Accidental & 0.2 & 0.6 & 1.2 \\
Negligent & 43.0 & 36.1 & 28.6 \\
Deliberate & 54.1 & 58.9 & 66.5 \\
Unknown & 2.0 & 4.1 & 3.4 \\
\hline
\end{tabular}

The reduced number of respondents is the cause of frequent multiple modal values.

Tab. 1, in particular, provides the percentage with which each motivation, as identified in Annex 1, was considered by the group of experts for its area. It is important to note that the most frequent motives (frequency $>10 \%$ ) are related to agricultural use of fire, followed by fire started as a result of labor conflicts.

\section{Discussion}

A number of interesting conclusions can be drawn from the results of the study.

The majority of respondents converge towards a rather limited number of motives (Tab. 2). More than $80 \%$ of the respondents actually refer to involuntary motives; namely, agricultural use of fire (codes 3101 , 3102, 3104).

In terms of frequency, responses by experts (even though operating in different areas) converge, reporting negligent fires as the most frequent set of motives (15 out of 32 ) and therefore confirming doubts expressed by some authors, as in the introduction, about the distribution of the percentage of causes (Bovio 2005, Corrado 2008).

Among voluntary motives, the most frequent one (gathering more than $50 \%$ of respondents and a frequency of $10.56 \%$ ), is referred to as "fire caused with the intent of being included in fire-fighting efforts" (motive code 4008), followed by motives referring to:

- harvesting mushrooms and edible sprouts, issued after passage of fire;

- protest of seasonal fire-fighters;

- pasture renewal;

- and pyromaniacs.

The results, apparently in contrast with the current public opinion that wants the majority of fires to be deliberate, are perfectly fitting with the point of view of international experts on the frequent overemphasis of voluntary causes of fire.

For the Regions involved in this study, Tab. 4 reports the percentage of fire causes from an in-depth official survey carried out in 2001 by the State Forestry Department (MIPAAF-CFS 2002).

With regard to motives, defined as the inner drive, reason or incentive that induces or prompts a specific behaviour, similar conclusions can be drawn from the results of rank ordering.

Instead of the usual summary of the overwhelming majority of causes as arsonist or unknown, the panel of experts resist to mundane explanations and attribute the majority of fire ignitions to cultural motives (for instance traditional use of fire, such as in the case of stubble burning) institutional behaviours (for instance protest against declaration of protected area, revenge against Public Administrations or Public Entities) or social tensions (e.g., ownership conflicts, labour conflicts) and give answers which appear to be rather homogeneous and convergent, despite the obvious difference of study areas.

Answers referring to high ranked motives are actually focused on a rather restricted, homogeneous group (Tab. 3) where a few motives cover more than $50 \%$ of possibilities. In detail, only 22 out of 43 possible motives $(51.16 \%)$ are considered by experts.

On the contrary, the less frequent and less important motives appear rather scattered, with few cases for each; results confirm, in any case, the absolutely scarce importance of

In the first rank order, i.e., scored 1 , the most relevant group is referred to as "agricultural use of fire", whereas a less important group of motives refers to deliberate fire setting (Tab. 3).

Expanding the comments to the first four ranks, motives connected to negligent fires are referred to as "careless use of agricultural fires" (codes 3101 to 3105), i.e., always with cultural motives.

The most frequent motive seems to be stubble burning (code 3104), i.e., systematic burning of stubble on wheat lands, for the sowing-purposes and the elimination of residue or thickets that restrict exploitation.

The principal aim of agricultural burnings is functional, i.e., they are not started simply for destructive purposes. These burnings are legally authorized as long as they comply with certain conditions, but become illegal as a result of failure to comply with preventive measures laid down by the regional laws. In any case, although the agricultural or shrub land burning may have started a fire, this natural and accidental fires. preparation of the agricultural land for new does not mean it ought to be considered as criminal use of fire.

Respondents give minor emphasis, in rank ordering, to the obvious and rather banal motive of cigarettes carelessly discarded which is, on the contrary, one of the most recurrent in the mentioned MIPAAF-CFS survey for 2001 in Italy (Matches and cigarette stubs abandoned or imprudently thrown along trails, roadways and train tracks account for $7.8 \%$ of total negligent fires, whereas agricultural accounts for $60.8 \%$, after that source).

Taking a look at deliberate fires, motives closely related to labour conflicts (groups 4006-4008) appear to be the most relevant ones in our study. These motives confirm the importance and presence of the so called "fire industry" (Leone \& Vita 1982, Leone et al. 1988, Leone \& Saracino 1990, Leone 1997a, Leone et al. 2003), i.e., voluntary fires lit by seasonal workers as an instrument for forcing/maintaining employment and/or creating new job opportunities (CFS 1992). Clearly, it is a case of fire being ignited as a means of subsistence, intentionally set by fire-fighters, as a way to maintain their job and increase their revenue (WWF 1993).

Deliberate fires of this kind are well correlated with the low level of income (Leone \& Vita 1982). The lower the level of income, the higher will be the number of provoked fires (Vélez 1986, Vélez 2000); the condition of marginality in areas where such events are common is confirmed by the economic classification of study-cases, all included in Objective 1 Regions, as already mentioned.

The motive referring to conflict with authorities (code 4103) is observed only in the National Park of Gargano, and is therefore not reported in Tab. 3 because of its local importance. This could be interpreted as a sort of reaction against land use restrictions in protected areas, which sometimes explodes in very violent ways. Confrontation can therefore occur, of which the forest fire is a symptom (FAO 2005), an unorthodox way of affirming rights of use (WWF 1993). The motive referring to conflicts with Public Administration (code 4101) could be interpreted in a similar way.

The motives which refer to ownership conflicts (code 4102) are ranked relatively low in terms of importance but have, in fact, importance in some limited areas, such as the Gargano National Park, as conflicts between shifting shepherds, not owners of grazing land but only landless occupants, and stable rural dwellers, indicating a social problem in the local cattle-farming system (Leone et al. 2002, Leone et al. 2003, Leone \& Lovreglio 2003).

The popular and abused motive which usually refers to fire used as a tool to convert rural land into urban land, i.e. building speculation (WWF 1993), is absent in the results. 
In any case building on areas swept by fire is not permitted for ten years by Italian Law $353 / 2000$.

Special mention must be made of pyromaniacs (code 4108), which received a rather high frequency, but ranked low in terms of importance in two study cases. As a matter of fact, the term "pyromaniac" is largely misused as a synonym of arsonist, not only in Italy but also in other countries (APAS 2003, Dolzreuss \& Irastorza 2005).

Psychologists, on the contrary, agree that pyromaniacs - people with a mental illness resulting in an uncontrollable urge to start fires - account for only a small minority of arson.

High scoring of this motive (but only in one area), could be interpreted as a case of being misinformed or a lack of information, and is further confirmation of confusion and common improper use of term, even by the experts. This calls for a more intense and improved training of people who are involved in forest fire statistics.

\section{Conclusions}

Knowing what motive induced or prompted a destructive behavior is critical to mount significant prevention efforts, which embrace measures that modify fuels and human behavior, so that the initiation, spread, and intensity of fires are reduced to such an extent that they can be controlled by the technical means available.

Causes of fires arise undoubtedly from many complex social, environmental, political, organizational and economic forces, whose importance is likely to vary by country or region and over time.

Results of this study confirm this variety from one area to the next, though some motivations are a recurrent and common core.

Understanding the motive behind the cause may enhance investigative efforts and focus on improving prevention and social behavior modification. Less emphasis should therefore be given to interventional actions an fire exclusion, which are mediatically impressive, whereas more attention and resources should be devoted to the analysis of complex causes of such social phenomenon (Folkman 1976) with the hopes of behavior modification of people.

Delphi, which is ultimately a structured process for collecting and "distilling" experience from a group of experts, reveals useful for this scope, since it exploits the experience and in-depth accumulation of knowledge of territory by professionals in a rather fast and simple way.

In the study areas of Southern Italy, the Delphi method allowed for placing the right emphasis on some motives, which can help to pinpoint appropriate preventive actions for the specific reality. Results confirm that wildfires are site and culture specific (Leone et al. 2003): the first issue of the study is that culture determines incendiary behaviour; the main action is, therefore, to change from a parochial, pragmatic approach and view the wildfire problem from a wider perspective, more careful of the society living in a territory.

For instance, in the case of fire set by means of stubble burning, it would be possible to allow fire use through regulation, zoning and periods of prohibition, by requiring burning licenses, together with the adoption of a set of measures to prevent fire escapes, such as peripheral plowing lanes (FAO 2005)

On the contrary, it would be much more difficult to establish actions against motives referring to voluntary fires set by firefighters as a way to maintain their job and increase their revenue, the so called "fire industry".

In Southern Italy, the use of labour in activities involving the cultivation and the protection of woods is mainly allocated to the maintenance of a minimum level of manual labour.

Wildfires voluntarily lit by member of seasonal firefighting crews in search of jobs, create and maintain work under the pressure of the events; authors take advantage of the emotional reaction of concerned communities who ask reinforcement of extinguishing activities: fire therefore creates new job opportunities, first in extinguishing the repeated fire events and then in replanting or restoring the burnt forests.

The results are more fires, more emotive attention, more people called to extinguish, but also more fires to maintain jobs, more fires to foster attention, turning into a permanent, vicious cycle.

Breaking this vicious cycle could be achieved by giving people alternative job opportunities in a more continuative way, for instance in prevention activities, such as preventive sylvicultural tending (thinning, pruning, prescribed burning) mainly making salary indifferent to repeated or provoked fire presence.

In conclusion, due to the increasing number of fires on the Mediterranean and national scale of the so called "fire club" countries, prevention must receive higher priority and greater attention than the improvement of fire suppression resources, which do limit damages but at such a cost that possibilities to increase those resources are nearly exhausted (FAO 2005).

In this context, the Delphi technique proves to be useful in helping fire managers in listing, identifying and in some way measuring the most frequent and relevant human caused ignition risks and sources.

In addition, it permits to give a sort of "weight" to fire motivations and, what is far more important, to lay down statistics at
NUTS 3 level or less, such as groups of municipalities; official statistics carried out by CFS in Italy are, on the contrary, usually referred at NUTS1 and NUTS 2 level and give only frequency of motivations.

For this, Delphi technique is a precious tool in the field of fire prevention and fire control planning.

\section{Acknowledgments}

The Authors thank prof. Emilio Chuvieco, University of Alcalà de Henares, Spain, for careful review and precious suggestions to improve text. A special thank is due to Kristy Schuster, from USA, for careful revision of English text.

\section{References}

Anderson DH, Schneider IE (1993). Using the Delphi process to identify significant recreation research-based innovations. Journal of Park and Recreation Administration 11 (1): 25-36.

APAS (2003). Estudio Sociòlogico sobre la Perceptión de la Poblacion Española hacia los Incendio Forestales. Associatión para la Promocciòn de Actividades Socioculturales [online] URL: http://www.idem21.com/descargas/pdfs/IncendiosForestales.pdf

Baughman MJ (1989). Effective use of the Delphi process. In: "Discovering new knowledge about trees and forests" (Leary RE ed). USDA, Forest Service, North Central Forest Experiment Station, Gen. Techn. Rep. NC-135.

Bovio G (2005). Incendi dolosi? In: "Foreste ricerca cultura. Scritti in onore di Orazio Ciancio" (Corona et al. eds). Accademia Italiana di Scienze Forestali, Florence, Italy, pp. 43-49.

CFS (1992). Aspects sociaux, economiques et culturels des incendies de foréts en Italie. In: Proceeding of the Seminar on "Forest Fire Prevention, Land Use and People". ECE/FAO/O1T, Athens (Greece) April 1987, pp. 45-59.

Corrado G (2008). Le azioni politiche per la difesa del bosco dagli incendi. In: Atti del III Congresso di Selvicoltura per la conservazione e il miglioramento dei boschi, pp. 345-354.

Clute O (2000). A perspective from wildland fire communicators. Wildland fire: Communicator's guide, The National Interagency Fire Center and the National Wildfire Coordinating Group. [online] URL: http://www.nifc.gov/preved/comm_guide/wildfire/fire_14.html

Crance JH (1987). Guidelines for using the Delphi technique to develop habitat suitability index curves. Biological report 82 (10.134), Fish and wildlife service national ecology center, Fort Collins, CO, USA.

De Las Heras J, Salvatore R, Rodrigues MJ, Lovreglio R, Leone V, Giaquinto P, Notarnicola A (2007). Wildfire motivation survey through the Delphi method. In: "Actas de la IV Conferencia Internacional sobre Incendios Forestales", Sevilla (España) 13-18 May 2007. [online] URL: http://www.fire.unifreiburg.de/sevill2007/contributions/doc/SESIONES TEMATICAS/ST4/Her as_et-AL_SPAIN_ITALY.pdf 
Dolzreuss ML, Irastorza FI (2005). State of the art of forest fire causes in Spain. In: Proceedings of the II International Conference on "Prevention strategies of fires in Southern Europe". Centre Tecnologic Forestal de Cataluña, Barcelona (Spain) 9-11 may 2005, pp. 325-331.

Dunham RB (1998). The Delphi technique. Wisconsin School \& Business web site, Winsconsin, USA. [online] URL: http://instruction.bus.wisc.edu/obdemo/readings/delphi.htm

Environment Policy (2003). Putting out the fire: saving Greece's forests. Environment Policy. [online] URL: http://www.greece.gr/ENVIRONMENT/EnvironmentalPolicy/AttackingTheRoot . stm Last Accessed 18.2.2003

FAB Consultores (1990). Estudio sobre la causalidad de los incendios forestales en la Comunidad Autonoma de las Islas Baleares.Conselleria d'Agricultura I Pesca. Govern Balear, Impresrapit.

FAO (1999). FAO meeting on public policies affecting forest fires. FAO Forestry Paper 138, UN Food and Agriculture Organization, Rome, Italy. FAO (2005). Community based fire management in Spain, April 2005. Forest protection working papers, working paper FFM/4/E. Forest resources development service, forest resources division. FAO, Rome, Italy. [online] URL: http:/www.fao.org/docrep/009/ag045e/ag045e00.HTM

FAO (2007). Fire management global assessment. A thematic study prepared in the framework of the Global forest resources assessment 2005. FAO Forestry Paper 151. FAO, Rome, Italy. [online] URL: http://www.fao.org/forestry/fra2005/en/

Folkman WS (1976). Vandalistic forest fire setting. In: Proceedings of the symposium "Vandalism and outdoor recreation" (Alfano SS, Magill AW eds). USDA For. Serv. Gen. Tech. Rep. PSW-17.

ICONA (1995). Motivaciones de los incendios forestales intencionados. ICONA Ministerio de Agricultura, Pesca y Alimentación, Madrid, Spain.

Jackson JW, Fisher RJ (2001). Keynote address, communities in flames conference, Balikpapan, Indonesia. [online] URL: http://www.fao.org/ docrep/005/AC798E/ac798e00.htm\#Contents Leone V (1997a). Sociological aspects in the phenomenology of forest fires. In: "The Forest and Man" (Ciancio O ed). Accad. Ital. Sc. Forest., Florence, Italy, pp. 305-324.
Leone V (1997b). Forest fires in Italy in 1995 and 1996. International forest fire news 17: 5-9.

Leone V, Koutsias N, Martinez Fernandez J, Allgawer B, Vega Garcia C, Lovreglio R (2003). The human factor in fire danger assessment. In: "Wildland fire danger estimation and mapping. The role of remote sensing data" (Chuvieco Salinero E ed). Series in Remote Sensing vol. 4, World Scientific Publishing Co., New Jersey, USA, pp. 143-194.

Leone V, Lovreglio R (2003). Parco nazionale del Gargano. Piano di previsione e prevenzione contro gli incendi boschivi (Unpublished internal report) [online] URL: http://www.minambiente.it/ Leone V, Lovreglio R (2003). Human fire causes: a challenge for modelling. In: "Innovative concepts and methods in fire danger estimation" (Chuvieco E, Martin P, Justice C eds). Proceedings of the " 4 th International Workshop on remote sensing and GIS applications to forest fire management". Ghent (Belgium) June 2003, pp. 149-170. [online] URL: http://www.fire.unifreiburg.de/fwf/Fire\%20Danger\%20Ghent\%20Proceedings.pdf

Leone V, Lovreglio R, Martinez Fernandez J (2002). Forest fires and anthropic influences: a study case (Gargano National Park, Italy). In: "Forest fire research \& wildland fire safety" (Viegas DX ed). Millipress, Rotterdam, The Netherland, pp. 11-28.

Leone V, Mazzucca D, Vita F (1988). Hypothesis as to the causes of forest fires in Puglia. In: Proceedings of the FAO/ECE/ILO "Seminar on methods and equipments for the prevention of forest fires". Valencia (Spain) Sept 3 - Oct 10 1986. ICONA, Madrid, Spain, pp. 190-198.

Leone V, Saracino A (1990). Arson and forest fire industry: the state of the art in Italy. In: Proceedings of the First International Conference on "Forest fire research". Coimbra (Portugal) 19-23 November 1990, pp. 13.1-13.9.

Leone V, Vita F (1982). Incendi boschivi e marginalità economica: il caso della Puglia. Cellulosa e Carta 7/8: 41-57.

Linstone HA, Turoff M (2002). The Delphi method techniques and applications (digital version). [online] URL: http://www.is.njit.edu/ pubs/delphibook/

Lovreglio R, Leone V, Giaquinto P, Notarnicola A (2006). New tools for the analysis of fire causes and their motivations: the Delphi technique. Forest Ecology and Management 234 (1): 18-33.
- doi: 10.1016/j.foreco.2006.08.034

Lovreglio R, Rodrigues MJ, Silletti G, Leone V (2008). Applicazione del metodo Delphi per l'analisi delle motivazioni degli incendi: il caso Taranto. L'Italia Forestale e Montana 5: $427-$ 447. - doi: 10.4129/IFM.2008.5.04

Ministerio de Medio Ambiente (1997). Diseño y planificación de acciones de comunicación para la prevención de incendios forestales. FAB Consultores, S. A., Madrid, Spain.

MIPAAF-CFS (2002). Indagine conoscitiva incendi boschivi. Ministero delle Politiche Agricole e Forestali, Corpo Forestale Dello Stato, Stampa New Graphic snc, Roma, Italy.

NASA (2003). Natural Hazards. NASA web site, Wasshington, DC, USA. [online] URL: http://earthobservatory.nasa.gov/NaturalHazards/ NASA (2009). Earthobservatory. [online] URL: http://earthobservatory.nasa.gov/GlobalMaps/vie w.php?d1=MOD14A1_M_FIRE

Schuster EG, Frissell SS, Baker EE, Loveless RS (1985). The Delphi method: application to elk habitat quality. USDA Forest Service, Intermountain Research Station, Research Paper INT353. Ogden, Utah, USA.

Turoff M (1970). The Design of a policy Delphi. Technological forecasting and social change 2: 149-171. - doi: 10.1016/0040-1625(70)90161-7

UNECE (2008). Forest fire statistics. UNECE Timber Committee, United Nations, Report ECE/TIM/BULL/2002/4. [online] URL: http://www.unece.org/trade/timber/ff-stats.html Wilson CC (1976). Detection and control of forest fires for the protection of the human environment. Project 0206-74-003, Publ. M/LO788/ E/1.78/1/70, FAO, Rome, Italy.

WWF (1993). Fires in the Mediterranean. [online] URL: http://www.env-edu.gr/Documents/Forest $\%$ 20fires\%20in\%20the\%20Mediterranean.doc

Vélez R (1986) Incendios forestales y su relación con el medio rural. Revista de Estudios Agrosociales. 136:195-224.

Vélez R (2000) La defensa contra incendios forestales. Fundamentos y experiencias. McGrawHill/Interamericana de España S.A.U., Madrid, pp. 2242.

Zuboy JR (1980). The Delphi technique: a potential methodology for evaluating recreational fisheries. NOAA technical memorandum NMFSSEFC-19, U.S. Dept. of commerce, National oceanic and atmospheric administration, National marine fisheries service, Washington, DC, USA. 